\title{
Konflik Kognitif Internal Siswa dalam Menyelesaikan Masalah Matematika Ditinjau dari Proses Asimilasi Akomodasi
}

\author{
Ratnah Lestary'1), Subanji ${ }^{2}$, Rustanto Rahardi ${ }^{3)}$
}

1,2),3) Universitas Negeri Malang, Indonesia

Correspondence: $\mathbb{M}$ ratnahlestary@gmail.com

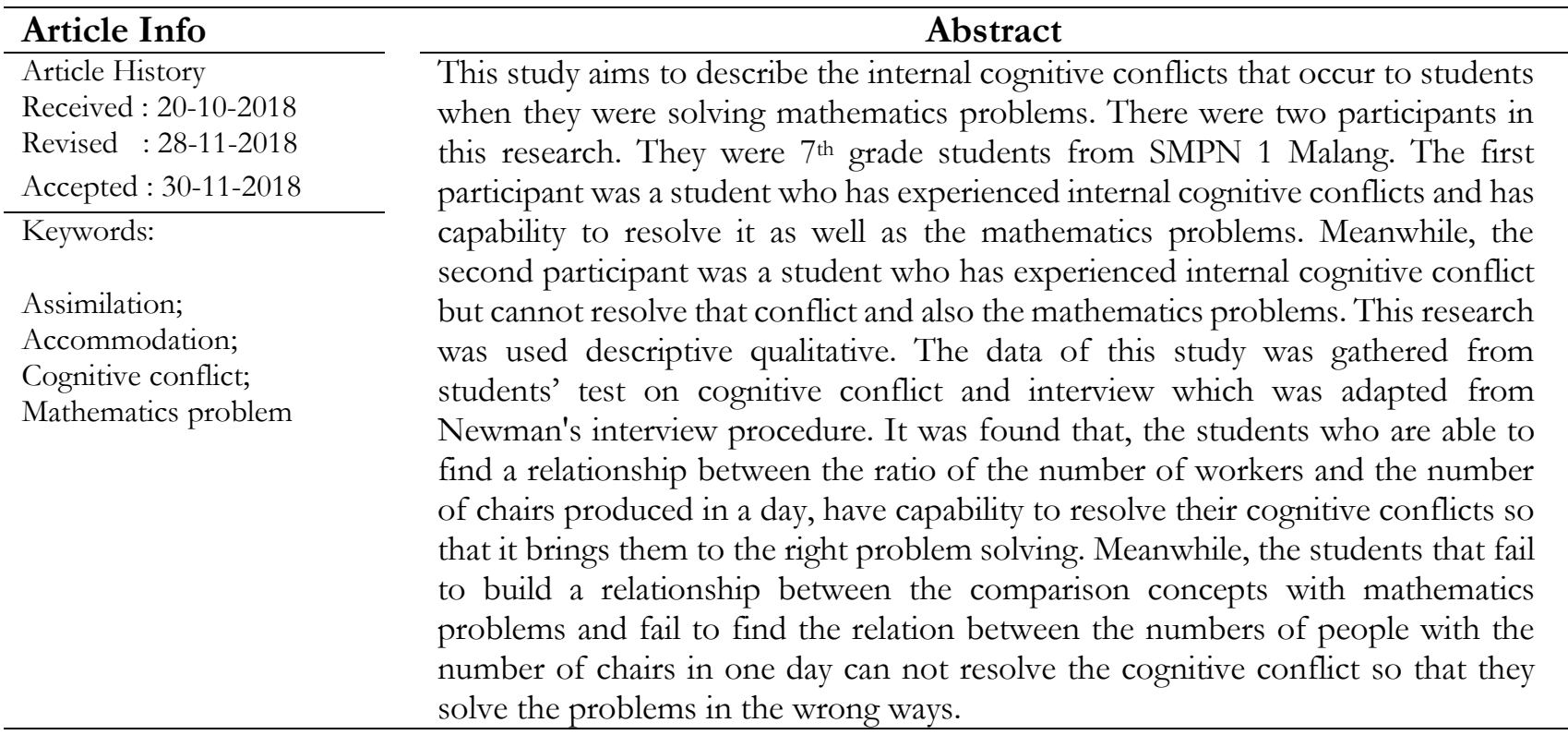

\section{PENDAHULUAN}

Salah satu ranah penilaian pada sistem pendidikan adalah kognitif. Pembelajaran di sekolah melatih perkembangan kognitif siswa melalui proses mengingat, memahami, menerapkan, menganalisis, menciptakan, mengevaluasi pengetahuan yang siswa dapatkan selama belajar. Hal ini sejalan dengan pandangan Piaget bahwa perkembangan kognitif anak terjadi secara aktif saat anak membangun sistem makna dan pemahamannya melalui pengalaman-pengalaman dan interaksi yang mereka alami [1].

Pada teori perkembangan kognitifnya, Piaget mengemukakan bahwa setiap individu beradaptasi. Adaptasi diartikan sebagai proses penyesuaian skema dalam merespon lingkungan dengan cara asimilasi dan akomodasi [1]. Ketika sesesorang menemukan suatu kondisi baru yang sesuai dengan skema yang ia miliki, ia akan melakukan adaptasi berupa asimilasi, sedangkan ketika skema yang ia miliki tidak sesuai dengan kondisi baru tersebut maka ia akan melakukan adaptasi berupa akomodasi [2]. Selanjutnya Piaget [3] mengatakan bahwa proses adaptasi akomodasi individu disebabkan oleh kondisi disequilibrium yaitu, ketidakseimbangan antara apa yang diketahui dengan apa yang ditemui. Kondisi kesulitan siswa dalam mengasimilasi pengetahuan baru ke dalam skema kognitif pada proses akomodasi tersebut ditunjukkan sebagai konflik. Berikut ilustrasi proses akomodasi dari Subanji (2016) yang disajikan dalam bentuk diagram untuk membantu memahami istilah konflik kognitif: 

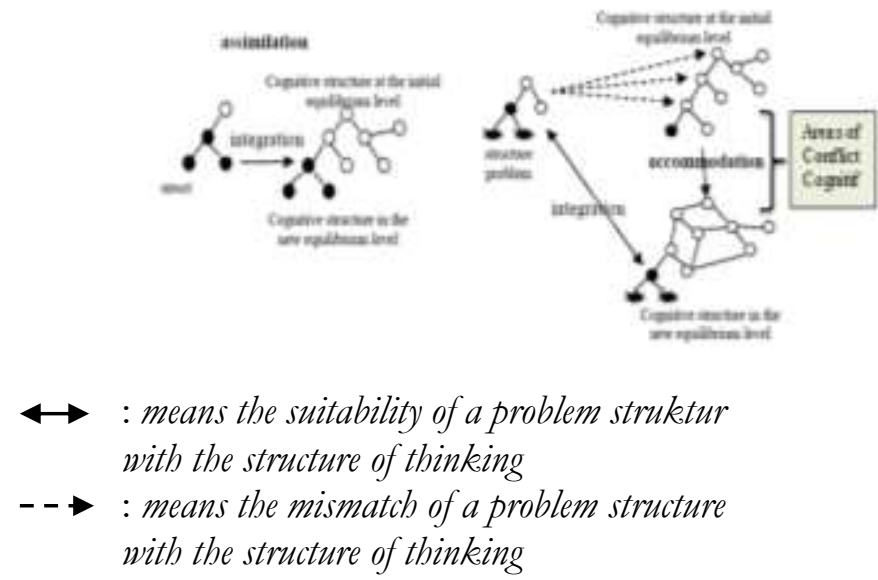

Gambar 1. Proses Asimilasi-Akomodasi Piaget (Adaptasi dari Subanji, 2015)

Selajan dengan pendapat Lee \& Kwon (dalam[4] yang menyatakan bahwa konflik kognitif adalah keadaan perseptual dimana seorang siswa memiliki pendapat yang berbeda antara apa yang ada dalam struktur kognitif mereka terhadap lingkungan atau informasi yang mereka dapatkan. Konflik kognitif yang dimaksud dalam penelitian ini adalah kondisi saat kognitif siswa mengalami pertentangan antara pengetahuan baru dengan pengetahuan yang ia miliki sebelumnya.

Konflik kognitif merupakan suatu kondisi yang sangat berpengaruh pada proses belajar siswa. Hal ini didukung oleh Piaget (dalam [1] yang menyatakan bahwa pembelajaran dapat diterima atau tidak oleh individu tergantung pada proses equilibrasi, yaitu proses pemulihan disequilibrium menjadi keadaan yang seimbang kembali (equilibrium). Ketika equilibrium sedang kacau, individu memiliki kesempatan untuk tumbuh dan berkembang. Shahbari \& Peled mengemukakan jika seorang siswa yang tertarik dengan situasi ini akan menunjukkan tanggapan seperti meningkatnya minat, rasa ingin tahu, dan perhatian yang terfokus. Keadaan ini mengakibatkan siswa berusaha melakukan proses equilibrasi guna mengatasi konflik kognitifnya hingga equilibrium tercapai kembali. Namun, seorang siswa yang cemas akan situasi ini akan menunjukkan respons seperti kebingungan, ketidaknyamanan, dan perasaan tertindas, sehingga konflik kognitif tidak dapat teratasi dan equilibrium menjadi sulit untuk tercapai [5]. Hal ini diperkuat oleh hasil penelitian [6] yang menunjukkan bahwa konflik kognitif merupakan langkah awal dalam proses perubahan konseptual dan kecemasan adalah komponen kognitif yang sangat penting, yang mempengaruhi hubungan antara konflik kognitif dan tanggapan siswa.

Konflik kognitif dapat muncul secara internal dalam struktur kognitif siswa dan ada juga yang harus diberi stimulus secara eksternal terlebih dahulu guna membangun sebuah pengetahuan baru. Sejalan dengan pendapat Strauss dalam [6] yang mengklasifikasikan konflik kognitif atas 2 jenis, yaitu konflik internal dan eksternal. Konflik internal merupakan konflik yang terjadi akibat bersaingnya dua ide dalam struktur kognitinya sendiri sedangkan konflik eksternal merupakan konflik yang terjadi akibat adanya interaksi dan komunikasi antara struktur dengan lingkungan.

Penelitian sebelumnya mencoba melihat fenomena konflik kognitif siswa dalam menyelesaikan masalah matematika. Berdasarkan dua penelitian berbeda yang dilakukan Wyrasti pada tahun 2016, terdapat dua fenomena berbeda pada subjek yang mengalami konflik kognitif saat 
menyelesaikan masalah matematika. Pada kedua penelitian subjek mengalami konflik kognitif internal, subjek pada penelitian pertama gagal menyelesaikan konfliknya yang berdampak masalah tidak terselesaikan. Sedangkan, subjek pada penilitian lainnya berusaha menyelesaikan konflik yang terjadi sehingga subjek berhasil mengkonstruksi sebuah informasi baru. Namun pada kedua penelitan tersebut tidak dijelaskan faktor penyebab mengapa siswa berhasil atau tidak berhasil mengkonstruksi informasi baru dalam menyelesaikan tugas matematika. Oleh sebab itu pada penelitian ini mengisi celah tersebut yaitu mendeskripsikan konflik kognitif internal siswa yang terjadi saat menyelesaikan masalah matematika serta menemukan faktor penyebab mengapa siswa tersebut berhasil atau tidak berhasil mengkonstruksi informasi baru saat mengalami konflik kognitif dalam menyelesaikan masalah matematika.

Penelitian ini menjadi penting karena guru perlu mengetahui lebih lanjut proses konflik kognitif internal yang terjadi pada saat siswa menyelesaikan masalah matematika. Khususnya pada proses bagaimana siswa dapat mengatasi konflik kognitif internalnya yang menyebabkan masalah matematika dapat diselesaikan dengan benar serta faktor penyebab siswa yang tidak dapat mengatasi konflik kognitif internal yang menyebabkan masalah matematika tidak terselesaikan dengan tepat. Sehingga guru dapat menentukan tindakan yang tepat untuk memberikan remedial atau pengayaan yang tepat serta memiliki pedoman guna melaksanakan pembelajaran selanjutnya.

\section{METODE PENELITIAN}

Jenis penelitian ini adalah deskriptif kualitatif. Data yang deskripsikan adalah proses konflik kognitif internal siswa SMP dalam menyelesaiakan masalah matematika. Tempat penelitian dilaksanakan pada SMP Negeri 1 Kota Malang tahun ajaran 2017/2018. Penelitian dilaksanakan pada tanggal 8-18 Maret 2018.

Subjek penelitian ini adalah dua siswa kelas 7 SMP Negeri 1 Kota Malang yang diberi kode CW dan FH. Dua subjek penelitian dipilih dari 26 siswa kelas 7 SMP Negeri 1 Kota Malang yang telah menyelesaikan masalah matematika dan memenuhi kriteria sebagai subjek penelitian. Kriteria pemilihan subjek penelitian adalah siswa yang menunjukkan setidaknya satu tanda-tanda konflik kognitif yaitu pengakuan kontradiksi, ketertarikan, kekhawatiran, dan penilaian kembali terhadap situasi kognitif pada lembar jawabannya [5].

Berdasarkan kebenaran jawaban, siswa dikelompokkan menjadi dua yaitu siswa dengan jawaban benar dan siswa dengan jawaban salah. Selanjutnya dipilih jawaban siswa yang menunjukkan tanda-tanda terjadi konflik kognitif terbanyak dari masing-masing kelompok sebagai subjek penelitian ini. Terpilih CW sebagai subjek dengan jawaban benar dan FH sebagai subjek dengan jawaban salah.

Instrumen yang digunakan pada penelitian ini berupa tes tertulis dan wawancara. Tes tertulis yang digunakan adalah tes penelurusan konflik kognitif internal. Tes penelusuran konflik kognitif ini berupa tes uraian yang terdiri dari satu permasalahan dan dua pertanyaan yang memandu siswa untuk menceritakan kronologis pemikirannya saat menyelesaikan permasalahan tersebut. Masalah matematika yang diberikan adalah masalah berkaitan dengan konsep perbandingan, sebagai berikut:

"Lima orang dapat menyelesaikan pembuatan 5 kursi dalam waktu 5 hari. Jika kemampuan setiap orang sama, berapa hari yang dibutubkan oleh 1000 orang untuk membuat 1000 kursi?"

Instrumen wawancara yang digunakan pada penelitian ini mengadopsi dari prosedur wawancara Newman. Hal ini merujuk dari pengalaman penelitian sebelumnya menemukan faktor- 
faktor penyebab siswa melakukan kesalahan dalam matematika [7]. Dilakukan wawancara terhadap dua subjek penelitian terlipih guna mengkonfirmasi proses konflik kognitif yang terjadi secara internal pada jawaban-jawaban yang telah dituliskan subjek penelitian pada lembar jawaban. Selain itu, tujuan dilakukan wawancara juga untuk mengetahui faktor-faktor penyebab siswa yang tidak dapat mengatasi konflik internal yang terjadi pada struktur kognitifnya dalam menyelesaikan masalah matematika berdasarkan ranah kesalahan menurut Newman [7]. Berikut kisi-kisi pertanyaan pada sesi wawancara siswa:

Tabel 1. Kisi-kisi pertanyaan wawancara tes penelurusan konflik kognitif internal siswa

\begin{tabular}{ll}
\hline \multicolumn{1}{c}{ Ranah Kesalahan } & \multicolumn{1}{c}{ Kisi-Kisi Pertanyaan } \\
\hline Membaca & $\begin{array}{l}\text { Adakah kata dalam soal yang tidak kamu ketahui } \\
\text { maknanya? }\end{array}$ \\
\hline Pemahaman & $\begin{array}{l}\text { Dengan bahasamu, bagaimana sebenarnya masalah } \\
\text { tersebut? }\end{array}$ \\
\hline Transformasi Matematika & $\begin{array}{l}\text { Jelaskan kepadaku bagaimana ide dan cara kamu } \\
\text { menyelsaikan soal! }\end{array}$ \\
\hline Proses Perhitungan & $\begin{array}{l}\text { Berilah penjelasan mengenai perhitungan yang telah } \\
\text { kamu buat sebelumnya! }\end{array}$ \\
\hline Menuliskan Jawaban Akhir & $\begin{array}{l}\text { Jelaskan bagaimana kamu menentukan jawaban } \\
\text { akhirmu! }\end{array}$ \\
\hline & $\begin{array}{l}\text { Apakah kamu sudah yakin dengan } \\
\text { jawaban akhirmu? }\end{array}$ \\
\hline
\end{tabular}

Teknik analisis data pada penelitian ini digunakan teknik analisis secara deskriptif kualitatif. Analisis data yang digunakan yaitu dengan mendeskripsikan proses konflik kognitif internal yang terjadi saat siswa menyelesaikan masalah matematika. Berdasarkan jawaban siswa dan hasil wawancara, dideskripsikan tanda-tanda dan konflik kognitif yang terjadi secara internal dalam struktur kognitif masing-masing subjek saat menyelesaikan masalah. Selanjutnya, dideskripsikan pula faktor penyebab bagi subjek yang tidak dapat mengatasi konflik kognitif internalnya sehingga menyebabkan masalah matematika tidak terselesaikan dengan benar.

\section{HASIL DAN PEMBAHASAN}

Hasil tes penelurusan konflik kognitif dari 26 siswa SMP Negeri 1 Kota Malang dalam menyelesaiakan masalah matematika disajikan pada tabel 3 berikut:

Tabel 2. Hasil Penelitian

\begin{tabular}{cccc}
\hline $\begin{array}{c}\text { Kategori } \\
\text { Jawaban }\end{array}$ & $\begin{array}{c}\text { Jumlah } \\
\text { Siswa }\end{array}$ & $\begin{array}{c}\text { Jumlah } \\
\text { Mengalami } \\
\text { Konflik }\end{array}$ & $\begin{array}{c}\text { Jumlah } \\
\text { Tidak } \\
\text { Mengalami } \\
\text { Konflik }\end{array}$ \\
\hline Benar & 4 & 2 & 2 \\
\hline Salah & 22 & 2 & 20 \\
\hline
\end{tabular}

\section{Tanda-Tanda Subjek Mengalami Konflik Kognitif Internal}

Konflik kognitif yang dialami oleh CW maupun FH terjadi secara internal tanpa adanya intervensi dari pihak luar. Tanda-tanda kedua subjek mengalami konflik kognitif diidentifikasi dari lembar jawaban serta hasil pengamatan peneliti terhadap perilaku subjek saat menyelesaikan masalah matematika yang diberikan. CW mengalami konflik kognitif ditandai dengan adanya 
pengakuan kontradiksi, ketertarikan, dan melakukan penilaian kembali terhadap ide awalnya. Berikut bukti dari CW mengalami konflik kognitif:

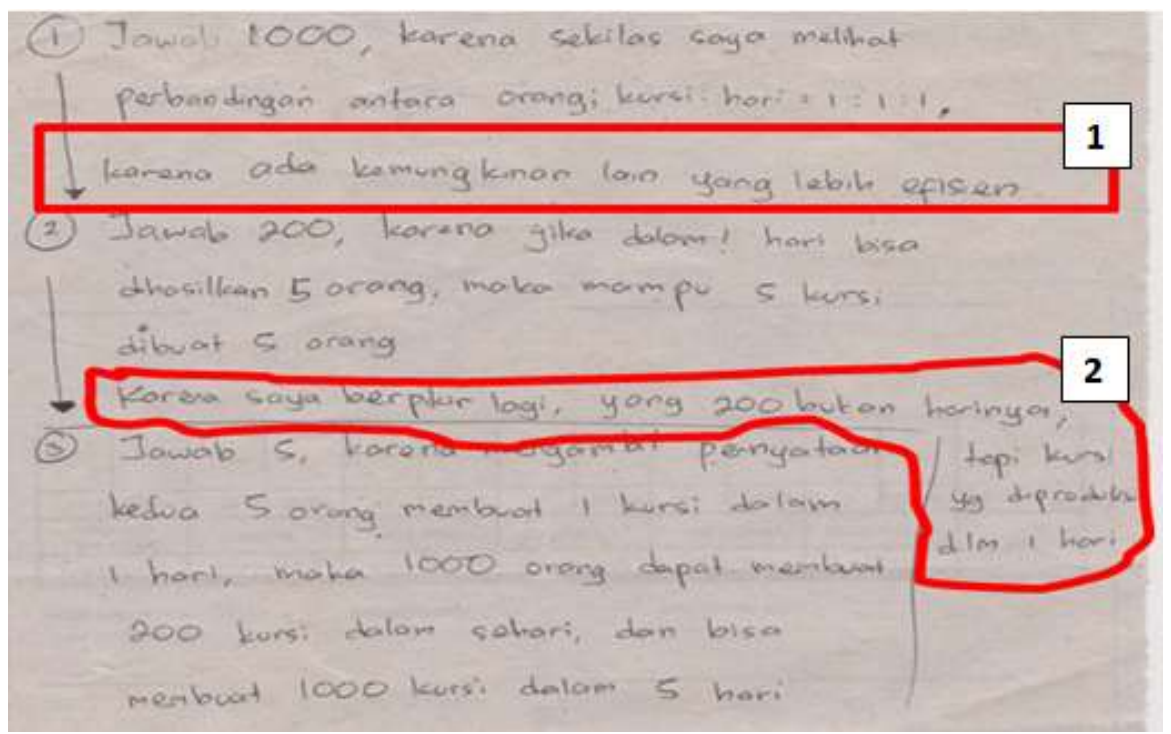

Gambar 2. Tanda Konflik Kognitif CW

Gambar 2 menunjukkan kronologi pemikiran CW saat menyelesaikan masalah matematika. Awalnya CW menjawab 1000 hari namun CW mencoba mencari kemungkinan jawaban lain (lihat bagian yang ditandai nomor 1) dan menemukan jawaban baru yaitu 200 hari. Usaha yang dilakukan $\mathrm{CW}$ untuk menemukan jawaban lain guna memastikan kebenaran jawaban awal merupakan tindakan penilaian kembali terhadap situasi kognitif [5]. Kemudian CW mengubah kembali jawabannya dengan 5 hari. Hal tersebut disebabkan CW menemukan suatu situasi yang kontradiksi (lihat bagian yang ditandai nomor 2), CW mengungkapkan bahwa nilai 200 yang ia dapatkan bukanlah jumlah hari namun jumlah kursi yang diproduksi selama 1 hari. Ungkapan yang dituliskan oleh CW tersebut merupakan pengakuan kontradiksi [5]. Berdasarkan kronologi jawaban yang dituliskan dan hasil pengamatan peneliti saat proses pengerjaan, CW menunjukkan ketertarikan dalam menyelesaikan masalah matematika yang diberikan. Hal ini juga merupakan tanda terjadinya konflik kognitif berupa ketertarikkan [5].

Terdapat tanda-tanda terjadinya konflik kognitif yang peneliti amati secara langsung selama CW menyelesaikan masalah matematika yang diberikan. Tanda-tanda konflik berupa perilaku subjek yang terjadi secara alami. Saat menyelesaikan masalah matematika CW seringkali bergumam, mengoyang-goyangkan pulpen, menunjukkan ekspresi wajah seperti merapatkan kedua bibir, dan memfokuskan pandangan dengan sedikit mengerutkan dahi saat membaca ulang jawaban yang sudah ia tuliskan pada lembar jawaban.

FH mengalami konflik kognitif ditandai dengan adanya pengakuan kontradiksi dan kekhawatiran. Gambar 3 menunjukkan kronologi pemikiran FH saat menyelesaikan masalah matematika. 

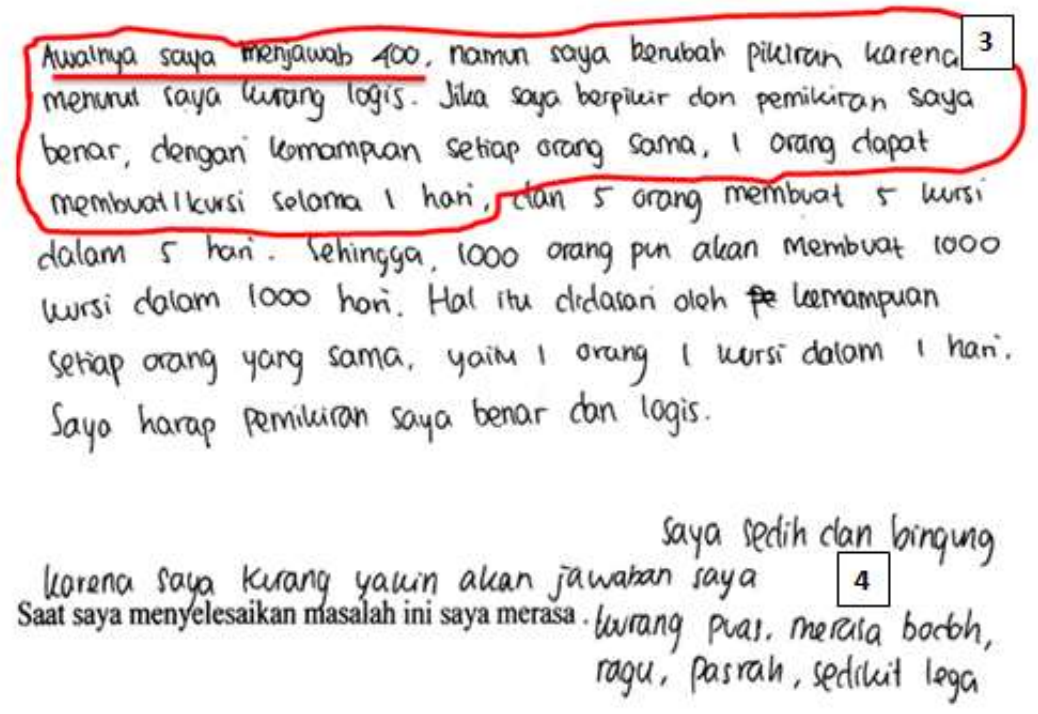

Gambar 3. Tanda Konflik Kognitif FH

Pada awalnya FH menjawab 400 hari namun FH merasa jawaban 400 hari tidak logis (lihat bagian yang ditandai nomor 3) dan menemukan jawaban baru yaitu 1000 hari. Keraguan yang dialami FH merupakan pengakuan adanya kontradiksi dalam struktur kognitifnya [5]. Selanjutnya FH mengungkapkan bahwa ia merasa bingung, sedih, kurang puas, merasa bodoh dan pasrah dengan keraguan yang ia alami saat menyelesaikan masalah matematika yang diberikan (lihat bagian yang ditandai nomor 4). Ungkapan yang dituliskan oleh FH tersebut merupakan tanda terjadinya konflik kognitif berupa kekhawatiran [5].

Hasil pengamatan peniliti saat $\mathrm{FH}$ menyelesaikan masalah matematika adalah $\mathrm{FH}$ juga menunjukkan tanda-tanda terjadinya konflik kognitif berupa perilaku. FH seringkali membolak balik lembar jawabannya, memegang kedua pipi, menundukkan kepala, dan sesekali membenarkan posisi duduk. FH terlihat sedang berdiskusi dengan dirinya sendiri sambil menunjuk nunjuk jawaban yang sudah ia tuliskan pada lembar jawaban, terkadang FH menggelengkan kepalanya, melontarkan pernyataan seperti "loh kog?", menganggukkan kepala, serta menghela napas panjang.

Kedua subjek penelitian menunjukkan perilaku seperti yang diperkirakan yaitu ketika siswa menyadari bahwa suatu situasi tidak sesuai dengan konsepnya, ia akan merasa tertarik dan/atau cemas tentang menyelesaikan ketidaksesuaian tersebut [6]. Pada kondisi tersebut, siswa berusaha mencoba mengatasi konflik kognitif dengan berbagai cara untuk mendapatkan penyelesaian masalah yang menurutnya sudah benar.

\section{Konflik Kognitif Internal Subjek $C W$}

CW menyimpulkan dengan benar bahwa jawaban dari masalah matematika yang diberikan adalah 5 hari. Lembar jawaban milik CW seperti yang disajikan pada Gambar 4. 


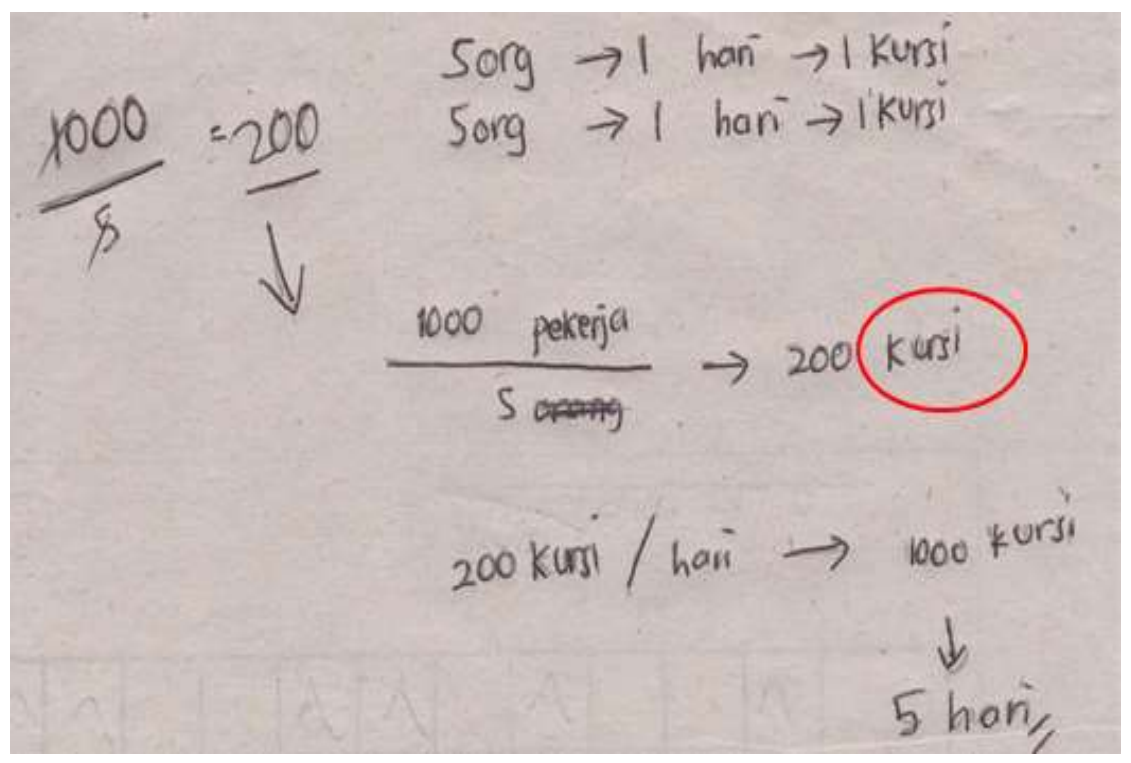

Gambar 4. Lembar Jawaban CW

Ditinjau dari kelima ranah Newman [7] saat dilakukan wawancara, CW dapat membaca soal dengan lancar, menjelaskan maksud dari permasalahan yang diberikan menggunakan bahasanya sendiri dengan benar, serta melakukan proses perhitungan dengan tepat. Terdapat hal yang menarik saat wawancara pada ranah transformasi matematika. Berikut potongan wawancara peneliti (P) bersama CW:

${ }^{1} \mathrm{P} \quad$ :"Melibat jawabanmu sampai ganti 3 kali, mengapa sampai begitu? Coba ceritakan Bagaimana ide dan cara kamu menyelesaikan masalah tersebut hingga kamu menemukan jawaban akbirmu?"

${ }^{2} C W$ :"Iya bu, soalnya menjebak, sekilas membaca soal ini 5 orang 5 kursi 5 hari, semua angkanya sama, artinya perbandingannya 1:1:1, jadi kalau 1000 orang 1000 kursi ya 1000 hari, awalnya saya langsung menebak seperti itu."

${ }^{3} \mathrm{P} \quad:$ :Ya, lanjutkan, mengapa sampai menemukan jawaban lainnya?"

${ }^{4} \mathrm{CW}$ :'Terus saya berpikir, apa benar jawaban ini, mengapa mudah sekali? Kemudian saya periksa kemungkinan banyaknya orang dengan kursi dalam 1 hari. Ternyata jika satu kursi dikerjakan bersama-sama oleb 5 orang itu selama 1 hari. Jadi saya bagi 1000 orang dengan 5, hasilnya 200."

${ }^{5} \mathrm{P} \quad: " Y a$, lalu?"

${ }^{6} \mathrm{CW}$ : "Tapi bu, 200 itu bukan harinya, hehe, tapi jumlah kursi yang dapat dibuat oleh 1000 orang dalam sehari."

"P :"Tapi dijawabanmu kamu tulis sebagai "kursi" (yang dilingkari merah)?"

${ }^{8}$ CW :"Kata kursi itu saya tulis setelah saya menyadari kalau 200 itu bukan hari bu, sebelumnya saya tidak. tulis keterangan disana."

${ }^{9} \mathrm{P} \quad$ : "Apa yang membuat kamu sadar dengan keadaan itu?"

${ }^{10} \mathrm{CW}$ :"Emm, begini bu, yang saya cari itu fokusnya adalah perbandingan jumlah orang dan kursi selama satu hari, mungkin tadi saya langsung mau menyimpulkan setelah dapat hasil bagi 1000 dengan 5 adalah 200 sebagai harinya, syukurny saya baca lagi, dan saya sadar kalau saya membandingkan pekerjanya maka yang saya dapatkan itu jumlah kursi selama sehari."

(Dialog 1)

Berdasarkan lembar jawaban dan hasil wawancara yang dilakukan terhadap CW diketahui bahwa pada ranah transformasi matematika CW menyadari skema awal yang dimiliki tidak dapat langsung diasimilasi untuk menentukan penyelesaian masalah (lihat Dialog 1 No.2-4). Sehingga CW melakukan proses akomodasi. Selama proses akomodasi CW melalui dua tahapan berpikir. 
Pada tahap pertama CW mengalami konflik antara skema awal yang dimiliki yaitu perbandingan $5: 5: 5=1: 1: 1$ dengan kondisi lain yang menggambarkan masalah yaitu 5 orang bersama-sama dapat membuat 1 kursi dalam sehari (lihat Dialog 1 No.4). Konflik kognitif ini muncul disebabkan adanya keraguan pada skema awal dan muncul ketertarikan untuk memeriksa kebenaran dari skema awal tersebut. Menurut [5] konflik pertama ini merupakan jenis konflik kognitif tipe II dengan tanda melakukan penilaian kembali terhadap ide awalnya. Pada akhir tahap ini CW mampu menentukan jumlah kursi yang dapat dibuat oleh 5 orang pekerja selama satu hari sebagai hasil dari konflik yang terjadi pada struktur kognitinya.

Pada tahapan kedua CW mencoba menemukan jawaban akhir dari masalah dengan membagi 1000 pekerja dengan 5 dan didapatkan hasil 200 (lihat Dialog 1 No.4). Awalnya, CW menyimpulkan bahwa hasil 200 yang didapatkannya merupakan jumlah hari yang dibutuhkan 1000 pekerja untuk menyelesaikan 1000 kursi. Namun, setelah itu CW kembali mengalami konflik kognitif antara jumlah kursi dan jumlah hari. Konflik yang terjadi dikarenakan CW menyadari adanya kesalahan interpretasi jumlah kursi dengan jumlah hari (lihat Dialog 1 No.6). Hal ini didukung oleh Stacey (2009) yang menyatakan bahwa tanda terjadinya konflik adalah saat siswa menyadari adanya kesalahan menginterpretasi suatu konsep dalam proses konstruksi pengetahuan yang dilakukannya. Pada akhir tahap kedua ini CW menemukan dengan jelas perbandingan banyak pekerja dengan banyak kursi yang dibuat dalam sehari (lihat Dialog 1 No.10) sebagai hasil dari konflik kedua yang terjadi pada struktur kognitinya.

CW mampu mengatasi setiap konflik yang terjadi dalam struktur kognitifnya hingga tuntas sehingga membawanya kepada skema baru yang dapat diasimilasikan untuk menentukan penyelesaian masalah dengan benar. Hal ini disebabkan CW mampu menemukan relasi antar jumlah pekerja dengan jumlah kursi dalam satu hari dengan benar. Proses konflik kognitif yang dialami oleh CW disajikan dalam bentuk bagan pada Gambar 5 berikut:

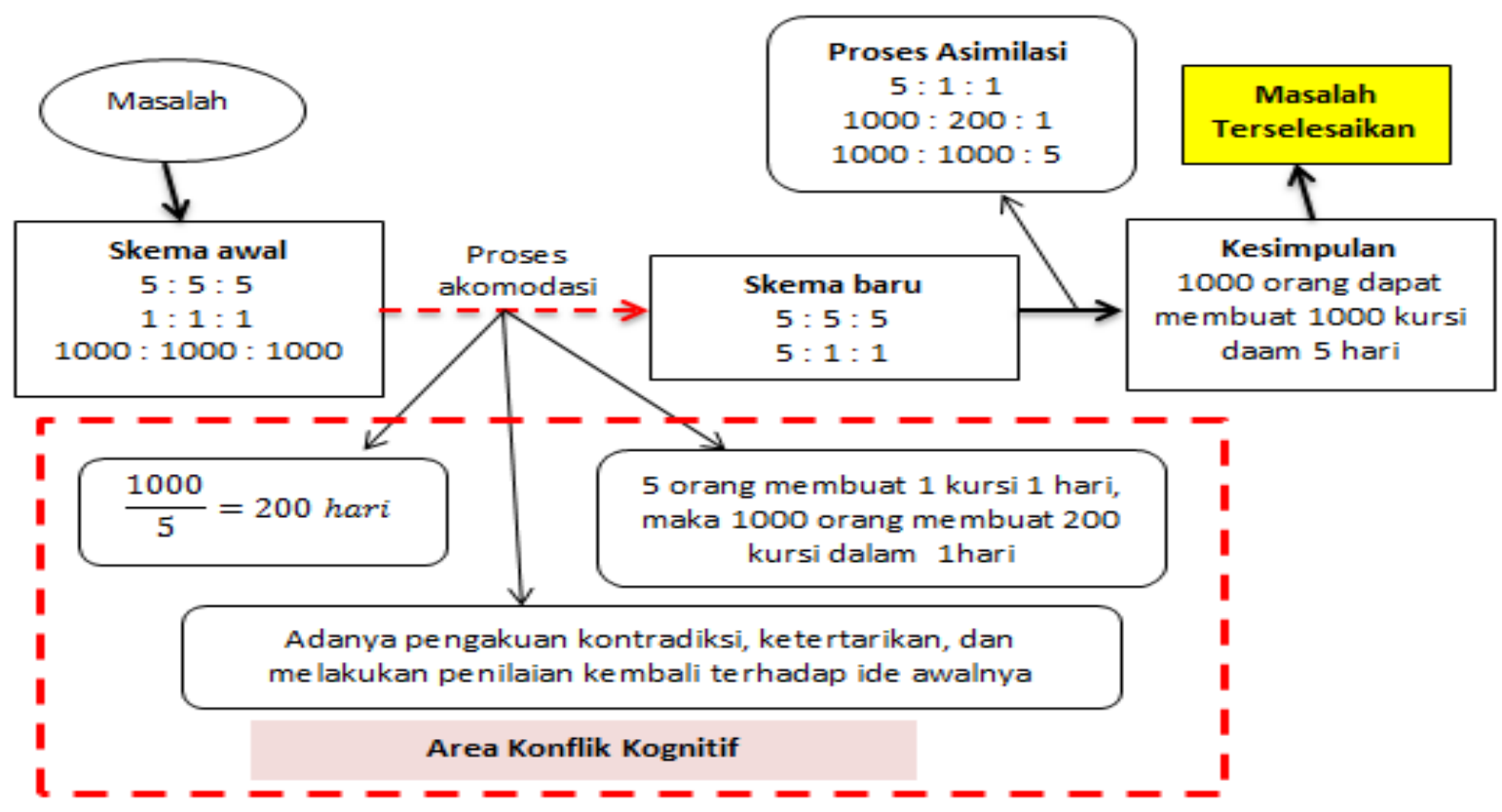

Gambar 5. Konflik Kognitif CW 


\section{Konflik Kognitif Internal Subjek FH}

FH menyimpulkan bahwa jawaban dari masalah matematika yang diberikan adalah 1000 hari. Penyelesaian yang diberikan oleh FH belum tepat. Berikut disajikan lembar jawaban milik FH (Gambar 6):

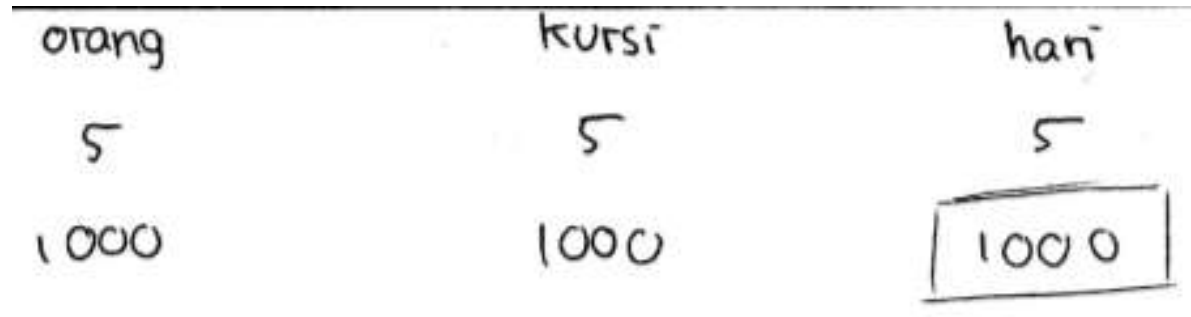

Gambar 6. Lembar Jawaban FH

Ditinjau dari kelima ranah Newman [7] saat dilakukan wawancara, FH dapat membaca soal dengan lancar dan menjelaskan maksud dari permasalahan menggunakan bahasanya sendiri dengan benar. Perhitungan yang dilakukan FH secara prosedural benar namun tidak membawa FH pada kesimpulan penyelesaian masalah matematika yang diberikan. Hasil perhitungan yang dilakukan oleh FH menjadi tidak benar dikarenakan adanya konflik kogntif yang tidak dapat diatasi oleh FH pada ranah transformasi matematika.

FH menyadari skema awal yang dimiliki tidak dapat diasimilasi dalam menentukan penyelesaian masalah. Sehingga FH melakukan proses akomodasi. Selama proses akomodasi FH melalui 3 tahap berpikir. Pada tahap pertama FH menyadari adanya kontradiksi antara hasil yang didapatkan menggunakan skema awal yaitu konsep perbandingan berbalik dengan hasil harapan yang ada pada struktur kognitifnya. Hal ini dibuktikan dari ungkapan FH yang bercetak tebal pada potongan wawancara berikut:

${ }^{1} P$ :"Sebelum kamu menyimpulkan jawabannya adalah 1000, kamu tuliskan bahwa kamu sempat menjawab 400. Coba ceritakan bagaimana ide dan cara kamu menyelsaikan masalab tersebut hingga kamu menemukan jawaban akbirmu?"

${ }^{2} \mathrm{FH}$ :"Kalau jawaban 400, saya dapatkan pakai perbandingan berbalik nilai bu, kalau 5 kursi kan 5 bari, kalau 1000 kursi dimisalkan y hari. Tapi itu salah sepertinya bu"

${ }^{3} P \quad:$ :Kenapa kamu memutuskan untuk menggunakan konsep perbandingan berbalik nilai?"

${ }^{4} \mathrm{FH}$ :"Karena ini jumlab pekerja dan jumlah hari, semakin banyak pekerja semakin sedikit hari bu"

${ }^{5} \mathrm{P} \quad$ : "Tya, lalu mengapa kamu menjadi tidak yakin dengan jawabanmu?"

${ }^{6} \mathrm{FH}$ :"Setelah saya mendapatkan hasil y nya adalah $\frac{1}{400}$ bu, jadi saya pikir jawabanya 400 hari, tapi jadi tidak logis dapatnya $\frac{1}{400}$ tapi saya simpulkan 400 hari. Mungkin karena ini ada 3 yang diketabui, orang, kursi, dan hari bu."

(Dialog 2)

Awalnya FH sudah memahami bahwa permasalahan matematika yang diberikan merupakan permasalahan matematika yang berkaitan dengan konsep perbandingan berbalik nilai (lihat Dialog 2 No.3-4). FH dapat menyebutkan ciri-ciri masalah perbandingan berbalik nilai, yaitu “. . . semakin banyak pekerja semakin sedikit hari bu”. Skema awal yang dimiliki FH adalah prosedur penyelesaian masalah perbandingan berbalik nilai yang diketahui dua variabel (lihat Dialog 2 No. 2). FH mencoba menerapkan skema awalnya tersebut untuk menyelesaikan permasalahan perbandingan berbalik nilai tiga variabel dengan mengabaikan variabel jumlah pekerja. Ketika FH mendapatkan hasil 
perhitungannya, ia merasa tidak menemukan penyelesaian yang sesuai harapannya. Keraguan (lihat Dialog 2 No. 2) dan pengakuan kontradiksi (lihat Dialog 2 No. 6) oleh [5] disebutkan sebagai tanda konflik yang dialami oleh FH dalam struktur kognitifnya. Sampai akhir tahap ini FH tetap pada konflik, equilibrasi gagal, dan FH tetap dalam keadaan disequlibrium.

Pada tahap kedua FH membaca ulang masalah matematika yang diberikan dengan lebih teliti. Hal ini dibuktikan dari ungkapan FH yang bercetak tebal pada potongan wawancara berikut:

${ }^{1} \mathrm{P}$ :"Baik FH, bagaimana kemudian kamu menyimpulkan 1000 bari?"

${ }^{2} \mathrm{FH}$ :"Em... Karena cara tadi tidak logis, saya baca lagi soalnya pelan-pelan, ada kalimat kemampuan setiap orang sama, jadi kalau 5 orang membuat 5 kursi dalam 5 bari, artinya 1 orang membuat 1 kursi dalam 1 hari. Maka 1000 orang membuat 1000 kursi dalam 1000 hari bu.

${ }^{3} \mathrm{P} \quad$ :"Sudah yakin dengan jawabanmu sekarang?"

${ }^{4} \mathrm{FH}$ :"Yakin bu."

(Dialog 3)

Pada tahap ini FH menunjukkan minat lebih terhadap masalah yang sedang dihadapi. Namun, pada sela-sela potongan percakapan FH seringkali mengungkapkan bahwa ia merasa bingung, takut jawaban yang ia tuliskan salah, merasa sedih, bahkan hingga mengungkapkan bahwa ia merasa bodoh karena permasalahan yang sedang dihadapi saat itu. Oleh [5] menyebutkan adanya tanda konflik yang dialami oleh FH yaitu berupa ketertarikkan dan kekhawatiran. Hal ini juga dibenarkan ketika seseorang menyadari bahwa suatu situasi tidak sesuai dengan konsepnya, dia akan tertarik dan / atau cemas tentang menyelesaikan ketidaksesuaian tersebut [6].

Pada tahap ketiga FH mengabaikan konflik kognitif yang terjadi sebelumnya. FH meninggalkan penyelesaian dengan menggunakan konsep perbandingan berbalik nilai dan menemukan kalimat yang menarik perhatiannya saat membaca ulang masalah, yaitu, “. . . kemampuan setiap orang sama ..." (lihat Dialog 3 No.2). FH mencoba menemukan relasi antara banyaknya pekerja, jumlah kursi, serta jumlah hari pengerjaan. Menurut FH, karena ada lima orang dengan kemampuan sama membuat lima kursi dalam waktu lima hari maka seorang pekerja membuat satu kursi dalam satu hari. Skema baru inilah yang digunakan FH untuk menyelesaikan masalah yang sedang dihadapinya. FH tidak menyadari bahwa relasi antara banyak orang, jumlah kursi dan jumlah hari yang ia simpulkan tidak benar. Sehingga akomodasi yang coba lakukan tidak berhasil. Piaget menggambarkan struktur kognitif FH pada saat itu gagal melakukan equilibrasi dan FH tetap dalam keadaan tidak seimbang atau disequilibrium [1].

FH tidak mampu mengatasi konflik yang terjadi dalam struktur kognitifnya dengan tepat. Hal tersebut menyebabkan skema baru yang ia dapatkan tidak membawa FH kepada penyelesaian masalah yang benar. Adapun penyebabnya adalah FH 1) gagal membangun hubungan antara konsep perbandingan berbalik nilai dengan masalah matematika dengan benar, 2) gagal menemukan relasi antar jumlah orang dengan jumlah kursi dalam satu hari dengan benar. Konflik kognitif yang dialami oleh FH disajikan dalam bentuk bagan pada Gambar 7 berikut: 


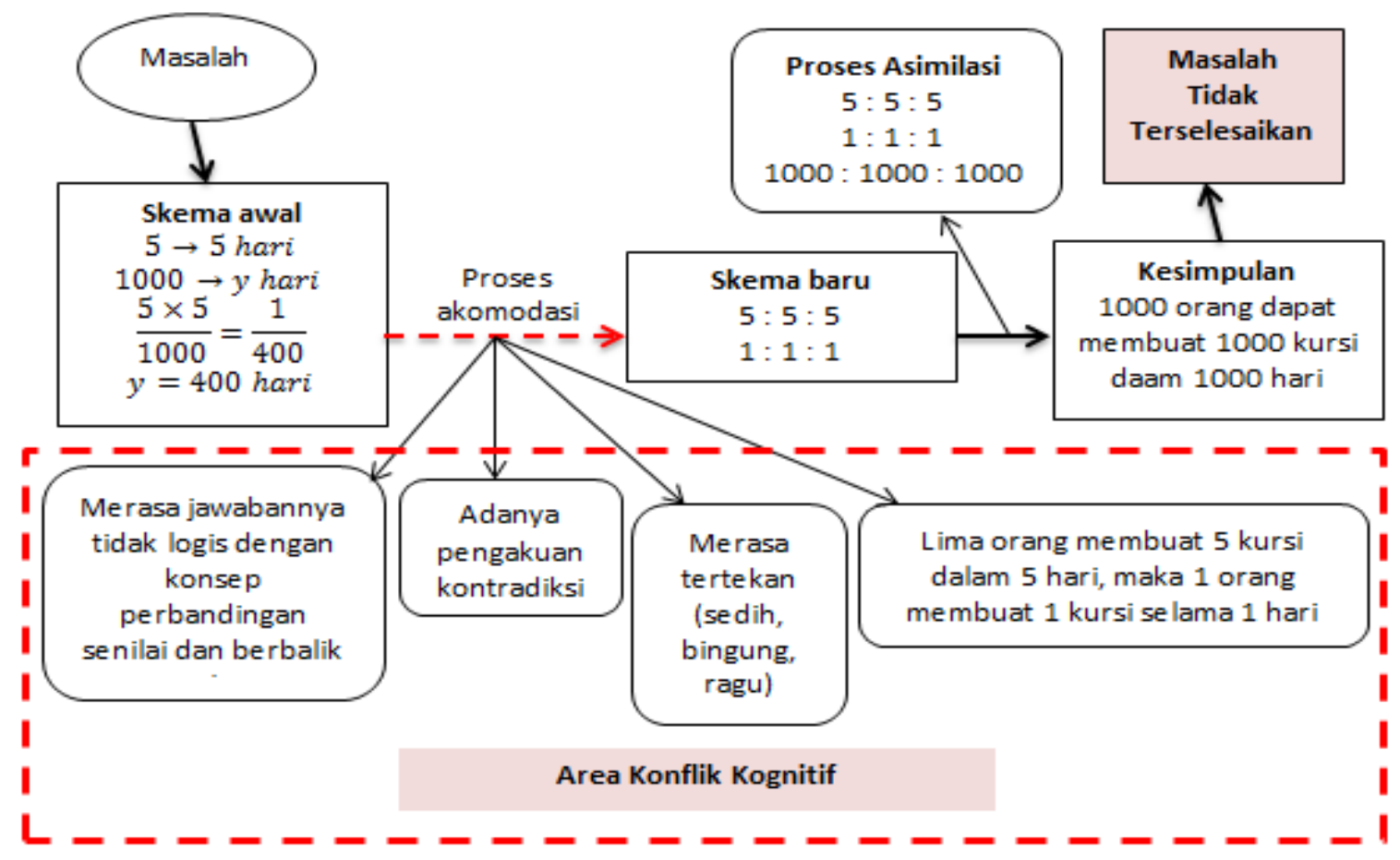

Gambar 7. Konflik Kognitif FH

\section{SIMPULAN DAN SARAN}

Kesimpulan dari penelitian ini adalah siswa yang mampu menemukan relasi antara perbandingan jumlah pekerja dan jumlah kursi yang diproduksi dalam sehari dapat mengatasi konflik kognitifnya hingga membawanya pada penyelesaian masalah dengan benar. Sedangkan siswa yang gagal membangun hubungan antara konsep perbandingan berbalik nilai dengan masalah matematika dengan benar dan gagal menemukan relasi antar jumlah orang dengan jumlah kursi dalam satu hari tidak dapat mengatasi konflik kognitifnya yang menyebabkan membawanya pada penyelesaian masalah yang tidak benar.

Berdasarkan temuan ini, disarankan dalam pembelajaran guru dapat menekankan relasi antar konsep-konsep perbandingan. Selain itu, hasil menunjukkan adanya indikasi bahwa siswa dengan pemahaman relasional dapat mengatasi konflik kognitif yang terjadi makan disarankan untuk dilakukan penelitian lanjutan berupa meninjau konflik kognitif yang terjadi pada siswa berdasarkan pemahaman matematikanya.

\section{DAFTAR PUSTAKA}

[1] R. E. Slavin,.

[2] S. Netti, T. Nusantara, S. Subanji, A. Abadyo, and L. Anwar, "The Failure to Construct Proof Based on Assimilation and Accommodation Framework from Piaget," International Education Studies, vol. 9, no. 12, p. 12, 2016.

[3] J. Sukoriyanto, N. Toto, S. Subanji, and D. C. Tjang, "Students thinking process in solving combination problems considered from assimilation and accommodation framework," Educational Research and Reviews, vol. 11, no. 16, pp. 1494-1499, 2016. 
Numerical: Jurnal Matematika dan Pendidikan Matematika, Vol. 2 No. 2 Desember 2018, 167-178

Ratnah Lestary, Subanji, Rustanto Rahardi

[4] A. F. Wyrasti, C. Sa, and L. Anwar, "The Assessment of Students' Cognitive Conflict by Using Student 's Cognitive Map in Solving Mathematics Problem,” no. 2006, pp. 72-82, 2016.

[5] G. Lee, J. Kwon, S. S. Park, J. W. Kim, H. G. Kwon, and H. K. Park, "Development of an instrument for measuring cognitive conflict in secondary-level science classes," Journal of Research in Science Teaching, vol. 40, no. 6, pp. 585-603, 2003.

[6] G. Lee and T. Byun, "An Explanation for the Difficulty of Leading Conceptual Change Using a Counterintuitive Demonstration: The Relationship Between Cognitive Conflict and Responses," Research in Science Education, vol. 42, no. 5, pp. 943-965, 2012.

[7] A. L. White, "Active Mathematics in Classrooms: Finding Out Why children make Mistakes - and then Doing Something to Help Them," Square One, vol. 15, no. 4, pp. 15-19, 2005. 